\title{
Liquid authority and political legitimacy in transnational governance
}

\author{
Forthcoming as: Kate Macdonald and Terry Macdonald, "Liquid Authority and Political \\ Legitimacy in Transnational Governance", International Theory, 2017, 9:2, pp.329-351
}

Kate Macdonald (University of Melbourne) and Terry Macdonald (University of Melbourne $)^{1}$

\begin{abstract}
In this article we investigate the institutional mechanisms required for 'liquid' forms of authority in transnational governance to achieve normative political legitimacy. We understand authority in sociological terms as the institutionalized inducement of addressees to defer to institutional rules, directives, or knowledge claims. We take authority to be 'liquid' when it is characterized by significant institutional dynamism, fostered by its informality, multiplicity, and related structural properties. The article's central normative claim is that the mechanisms prescribed to legitimize transnational governance institutions - such as accountability or experimentalist mechanisms-should vary with the liquid characteristics of their authority structures. We argue for this claim in two steps. We first outline our theoretical conception of political legitimacy-as a normative standard prescribing legitimizing mechanisms that support authorities' collectively valuable governance functions - and we explain in theoretical terms why legitimizing mechanisms should vary with differing authority structures. We then present an illustrative case study of the interaction between liquid authority and legitimizing mechanisms of public accountability and pragmatic experimentalism in the context of transnational business regulation. We conclude by considering broader implications of our argument for both the design of legitimate transnational governance institutions, and future research agendas on transnational authority and legitimacy.
\end{abstract}

\section{Introduction}

The interdependent lives of global populations are structured by a dense web of political institutions extending far beyond the rigid legal, bureaucratic, and coercive apparatuses of states. These institutions are politically sustained and steered through a complex system of transnational governance - which depends to a significant degree on authoritative instruments for fostering compliance with its institutional directives, rules, or knowledge claims. For our purposes here we adopt the account of transnational authority presented by Nico Krisch in his introductory contribution to this symposium. As Krisch has explained, authority is here defined sociologically to incorporate all institutionalized powers for fostering compliance that operate by inducing deference, rather than through coercion or persuasion. Moreover, much

\footnotetext{
${ }^{1}$ We would like to acknowledge financial support from the Australian Research Council in carrying out this research.
} 
transnational authority can now be understood as 'liquid' rather than 'solid' in character, whereby liquid authority is contrasted with solid authority in virtue of being dynamic rather than settled in its content or scope. This dynamism can result from interactions among the authority's broader structural properties - most importantly its informality, with respect to the legal status of its bindingness on subjects, and its multiplicity, with respect to the reasons for action that it can issue, as well as the range of authorities and addressees of authority claims (Krisch, this volume).

In this article we address the question: what institutional mechanisms are required for 'liquid' forms of authority in transnational governance to achieve normative political legitimacy? By normative political legitimacy, we mean a standard of political acceptability for authoritative institutions - such that the addressees of legitimate transnational authorities have sufficient normative grounds to defer to these authorities, and ought therefore to defer. Our central concern with understanding the basis on which transnational institutions can acquire legitimacy builds on a significant body of established scholarship, which has empirically highlighted increasingly fragmented, informal, dynamic and interactive transnational governance processes, and begun to acknowledge potential implications for political legitimacy. Our analysis seeks to demonstrate the value of the 'liquid authority' concept in facilitating more systematic analysis of the normative implications of shifting transnational authority structures for political legitimacy.

We argue that the mechanisms prescribed to legitimize transnational governance institutions (such as what we will refer to as accountability or experimentalist mechanisms, for example) should vary with the solidity or liquidity of their authority structures. This argument has important prescriptive implications for the design of transnational governance institutions: we should resist 'one-size-fits-all' institutional prescriptions for legitimizing transnational authorities, and instead develop more contextually variable models that are sensitive to empirical analyses of authorities' distinctive structural characteristics.

Our discussion begins with a brief survey of established scholarship on the problem of political legitimacy in transnational governance-locating the significance of the liquid authority research agenda within this wider field of inquiry. To develop our argument from this base, we then present our theoretical conception of political legitimacy-as a normative standard prescribing legitimizing mechanisms that support authorities' collectively valuable governance functions - and we explain theoretically why such legitimizing mechanisms should vary with differing authority structures. Next, we present an illustrative empirical case study analysis of the interaction between liquid authority and legitimizing mechanisms of public accountability and pragmatic experimentalism in the context of transnational business regulation. Our case focuses on liquid authority in transnational governance institutions that operate to regulate transnational business activity—specifically, company-community land disputes within the palm oil sector. This represents an increasingly visible field of transnational governance in which liquid features of authority have been widely documented (Cashore 2002, Cutler, Haufler, and Porter 1999, Hall and Biersteker 2002), and the legitimacy of such authority has been contested. Investigating suitable institutional mechanisms for legitimizing liquid authority within a specific issue area of transnational governance such as this enables us to develop a more contextually 
sensitive and empirically nuanced analysis than could be achieved through a purely theoretical inquiry. We conclude with some further reflections on the broader implications of our analysis for both the design of legitimate transnational governance institutions, and future research agendas on transnational authority and its normative legitimacy.

\section{Legitimizing authority in transnational governance}

The institutional problem of political legitimacy in transnational governance As scholarship on transnational governance has developed during the post-Cold War decades, growing attention has focused on the problem of normative political legitimacy. The first major wave of theoretical work on normative transnational political legitimacy was led by cosmopolitan scholars, who explored the prospects for developing legitimate governance institutions beyond the nation state (Pogge 1992, Held 1995, Cabrera 2005). Cosmopolitan institutional prescriptions have varied substantially: some scholars have developed accounts of legitimate transnational authority that are based on strong world state structures (Cabrera 2005); others have endorsed more loosely integrated (but nonetheless somewhat stable and legally formalised) systems of political authority at local, national and global levels (Archibugi 2008, Habermas 2013, Held 1995, Pogge 1992). Cosmopolitan institutional models have nonetheless cohered around a broadly optimistic stance towards the prospects of creating relatively solid structures of transnational political authority as a basis for legitimate governance. Correspondingly, the mechanisms favoured by cosmopolitan scholars for legitimizing transnational authority have closely resembled those instituted within democratic states, with a focus on electoral - or otherwise formally structured democratic processes of participation or representation.

The cosmopolitan approach can be contrasted in subtle but significant ways with what we call a transnationalist governance literature. This work has been predominantly empirical, and focused on exploring the operation of political authority in the existing world order - which has not come close to resembling any constitutionally structured cosmopolitan model, and in which evolving systems of transnational and private authority, informal authority, or so-called 'soft law' play central roles. Through engagement with this empirical research, some normative theorists have recognized that informal and fragmented authority structures can present challenges both for the effective functioning of governance systems, and for the task of identifying a stable and cohesive public to participate in centralized legitimizing processes such as those prescribed by cosmopolitan democrats (Scholte 2004, Skelcher 2005, Bernstein and Cashore 2007, Black 2008, Macdonald \& Macdonald 2010, Macdonald 2011). These challenges have led many to prescribe alternative models of accountability, representation, or localized deliberation and direct participation, that can in some respects better accommodate shifting and overlapping authority structures and corresponding publics (Zurn 2004, Macdonald 2008, Bohman 2007, Dryzek 2006, Steffek 2003).

A third and more recent wave of scholarship has focused on dynamic or interactive configurations of transnational authority-building on and extending wider transnationalist analysis of the non-unitary character of transnational governance (Eberlein et al 2014, Abbott and Snidal 2009, Gehring and Oberthur 2009, Zurn and Faude, 2013). This work has been mainly empirical, incorporating only tangential 
engagement with the problem of normative political legitimacy. Analysis of the implications of dynamic governance interactions for institutional effectiveness (Eberlein et al 2014, Meidinger 2008, Overdevest and Zeitlin 2014, Duit and Galez 2008) has potentially important implications for analysis of legitimacy, though such links have not been systematically explored. Some theoretical work focused on national, sub-national or supranational governance contexts (Papadopolous 2003, Kjaer 2010) has examined the capacity for legitimization in the presence of dynamic, interactive forms of governing authority, though there is little such analysis focused on the transnational level (for exceptions see Little 2015, Kuyper 2014, and Black, this volume).

Considered as a whole, established scholarship on the legitimization of transnational governance authority has made a number of moves that are noteworthy for our purposes. It has highlighted the increasingly non-unitary and fragmented character of transnational governance, and the importance of non-legal forms of governing authority. Moreover, it has explicitly acknowledged that empirical facts about shifting social and institutional formations have important implications for normative debates on the legitimacy of transnational governance. Nonetheless, the recognition that normative political legitimacy confronts special challenges at the transnational level has not yet engendered a clear framework for understanding the relationship between different formations of authority and legitimacy. As we illustrate in what follows, the concept of liquid authority provides a useful conceptual tool for more systematic analysis of the normative implications for legitimacy of fragmented, informal, dynamic and interactive transnational governance processes.

The normative grounds of legitimate authority

In order to assess what institutional mechanisms are required for 'liquid' forms of transnational authority to achieve normative political legitimacy, we must begin by taking a step back from concrete particulars of institutional design proposals, and considering in more detail the underlying normative grounds for judging authoritative institutional arrangements as politically legitimate. The character of these normative grounds is one of the most complex and contested issues within the theory of political legitimacy, and views on this issue vary considerably.

A widespread view has been that institutional standards of legitimacy are grounded in other substantive political values. For example, some claim that authorities can only be judged politically legitimate when they comply with suitable principles of distributive justice (Valentini 2012), or conform to an ascribed democratic political ideal (Dryzek 2001). In recent literature, however, several theorists have argued that institutional standards of legitimacy cannot be viewed as wholly derivative of these other values, and must instead be attributed independent normative grounds. One broad approach seeks to draw these grounds from moral philosophy, arguing that legitimacy is concerned with the protection of certain fundamental moral values distinct from those of either democracy or distributive justice (Erman 2015). Another family of approaches seeks to draw these grounds instead from political analysis, linking them to the value of solving certain complex political problems - such as the problem of political order (Williams 2005), or of motivating social cooperation through institutions when both material interests and moral values diverge (Buchanan and Keohane 2006). 
Here we adopt a view of the normative grounds of political legitimacy that can be located broadly within this latter family of approaches. We call this a 'collective agency' account. On this view, the normative grounds of legitimacy claims are located ultimately in the value of the collective political action that legitimate institutions help to sustain. As such, an authoritative institution is legitimate to the extent that it is able to function as a vehicle for its addressees to advance their shared values effectively (Macdonald $2015 ; 2016)$. These shared values may be moral in character-such as that of social justice-or they may rest on common interests of other kinds. Either way, the legitimacy of authoritative institutions depends not on an evaluation of the moral worth of the values they advance, but rather on an assessment of these institutions' functional capacity to facilitate collective action among their addressees in pursuit of values that they share.

\section{Institutional mechanisms of legitimization in transnational governance}

There may at least in principle be some conditions under which the exercise of authority is itself sufficient to motivate deference to collectively formulated rules or aims, and thus to facilitate desired forms of collective action. But we assume that under most real political conditions, efforts by authoritative institutions to facilitate such collective action confront a range of difficulties-such as challenges in identifying clear and stable agreement on the content of collective rules or aims, and ongoing potential for abuse of authoritative powers. Consequently, legitimate authoritative institutions generally need to incorporate some remedial institutional mechanisms of legitimization, which serve to strengthen the functional capacities of institutional authorities in the face of these kinds of threats.

Analyses of legitimizing institutions formulated for application to nation-states (or a cosmopolitan world state) have generally not focused on the idea of institutional mechanisms, as we are doing here, but rather on institutional structures (Rawls 1999) or schemes (Pogge 1989)-devised for implementation at a holistic societal level. The clearest examples of these are constitutional institutional schemes-such as those embodied in familiar designs for constitutionalized legal institutions or democratic institutions for collective political decision-making-which aim to satisfy both necessary and sufficient conditions for an institutional authority to achieve political legitimacy. Our focus instead on discrete institutional mechanisms of legitimization reflects our assumption that constitutionalized schemes cannot be accomplished on a transnational scale (at least within any proximate timeframe). This is in line with the broader shift, described by Michael Zürn in this issue, from constitutional rule to loosely coupled spheres of authority. As such, we take it that transnational legitimization can best be accomplished, for now, through more piecemeal assemblages of mechanisms that contribute only partially, and in differing degrees, to authorities' political legitimacy.

The general function of such legitimizing mechanisms is to regulate relationships between authorities and their addressees so as to make the value of the authorities more motivationally salient for their addressees-and thereby more successful as vehicles for collective action. This can be achieved through institutionalizing two kinds of processes: first, a process for strengthening or sustaining the collectively valuable functions of the institutional authority in question; and second a process for providing public assurance to addressees that this is occurring. Varying institutional mechanisms 
of legitimization can then be distinguished on the basis of how they structure these respective institutional processes of functional support and public assurance.

A number of legitimizing mechanisms have been acknowledged as important in a transnational governance context, and received sustained attention within established literatures on transnational legitimacy. These include deliberative mechanisms (Steffek, 2003) and those that harness expertise (Quack, 2010), as well as the two legitimization mechanisms that we focus on in this paper-public accountability and pragmatic experimentalism - which play central roles in the detailed case study we present below. What we call public accountability, first, is a subset of a broader range of 'accountability' mechanisms that have been extensively discussed over the last decade in debates on transnational governance and legitimacy (Clapp 2005, Goodhart 2014 , Grant and Keohane 2005, Held and Koenig-Archibugi 2005, Kahler 2009, Newell 2008, Scholte 2004, Zurn 2004). By accountability, we mean an institutionalized relation in which one agent (or group of agents) is accorded special entitlements to question, direct, sanction or constrain the actions of another-particularly where these actions involve the exercise of authority within a governance system (Bovens 2007, Goodhart 2014 , Koenig-Archibugi 2010, Mulgan 2000). By public accountability, we mean a specific 'standards-based' model of accountability, in which accountability relies on the clear identification of standards defining responsible conduct for specified actors, together with provision of some external means of inducing compliance with these standards, and providing appropriate redress in instances of non-compliance.

Public accountability mechanisms of this kind can contribute to the political legitimization of an authority through their special processes for strengthening and publicly demonstrating the authority's functional value. First, public accountability mechanisms can support the valuable functions of an authority through processes for publicly articulating and codifying clearly defined standards for its conduct or the outcomes of its action, based on the shared expectations of the authority's addressees. Second, these mechanisms can provide public assurance to addressees that these standards are being satisfactorily met through processes of public reporting or answerability by authorities. This provides opportunities for addressees or other agents to impose public consequences upon authorities if expectations are not met-whether in the form of a withdrawal of support, penalties, or a demand for justification. In this way, public accountability mechanisms can help to increase the motivational salience to addressees of an institutional authority's value, thereby strengthening its political legitimacy.

What we call pragmatic experimentalism, second, is a family of institutional mechanisms that has only more recently begun to attract serious attention from transnational governance scholars. Experimentalism, broadly conceived, is an institutionalized process of inquiry-based problem-solving, developed by the classical American pragmatist John Dewey, and adapted by a range of contemporary scholars (Dorf and Sabel 1998, Sabel and Zeitlin 2008, Búrca 2010). Earlier work on experimentalist governance focused on developing an institutional model labelled democratic experimentalism, which proposed embedding local experimentalist mechanisms within complex administrative states (Dorf and Sabel 1998). At the transnational level, however, experimentalist mechanisms adopt a looser structure more divorced from democratic constitutions, which can be understood as: 
an institutionalized process of participatory and multilevel collective problem solving, in which the problems (and the means of addressing them) are framed in an open-ended way, and subjected to periodic revision by various forms of peer review in the light of locally generated knowledge (Búrca, Keohane, and Sabel 2014: 477).

Here we use the label pragmatic experimentalism to refer to transnational experimentalist mechanisms of this broader kind. Pragmatic experimentalist mechanisms contribute to the political legitimization of an authority through processes for strengthening and publicly demonstrating the authority's functional value, but through different mechanisms from public accountability. Whereas public accountability supports the valuable functions of authorities via codifying regulatory standards, experimentalist mechanisms deploy looser standards in which addressees' expectations regarding authorities' actions remain more open to transformation and revision, in accordance with the evolving outcomes and opportunities generated by experimental action. Experimentalist mechanisms provide public assurance of an authority's valuable functions by engaging addressees in collaborative experimental action, constituted by varying forms of negotiation, inquiry, exploration through action, and assessment of outcomes - all of which function to generate 'possibilities for responsive and effective problem solving in an iterative and non-hierarchical fashion' (Búrca, Keohane, and Sabel 2014: 480).

\section{Adapting legitimizing mechanisms to liquid transnational authority structures}

Drawing on the preceding theoretical analysis, we can identify an analytic strategy for identifying and justifying institutional mechanisms of legitimization within varying governance contexts. This strategy involves systematic reflection on three questions, in light of salient facts. First, what is the valuable function of the particular authoritative governance institution being subject to a legitimacy assessment? Second, what are the systemic threats to this institution's valuable functions given the particular circumstances of its operational context? And third, what are some plausible institutional remedies to those threats within this context? (Macdonald 2016) We employ this strategy in the following case study discussion of transnational companycommunity land disputes to analyze how institutional mechanisms should vary with the liquidity of authority in that particular governance context. We make particular reference to the roles of public accountability and pragmatic experimentalist mechanisms, as we explain further below.

Before doing so, however, it is helpful to consider why and how we might expect the liquidity of authority to shape the selection and justification of legitimizing mechanisms. Building on the account we have given of the nature of legitimizing mechanisms, and the normative grounds on which particular mechanisms can be justified as suitable for legitimizing authorities within particular governance contexts, we can sketch two broader theoretical propositions in answer to the question: how should legitimizing mechanisms vary with the degree of liquidity in particular contextual structures of transnational authority?

First, we propose that liquid authority structures will have implications for the kinds of institutional mechanisms required to support authorities' valuable governance functions effectively, insofar as liquidity can affect the functional capacities of authorities with respect to advancing particular collective values. For example, liquid characteristics of 
multiplicity and dynamism may create special functional challenges for authorities committed to advancing the value of equal individual rights protections, by constraining authorities' capacity to establish the relevant population of addressees among whom such equal political powers and protections could be systematically secured.

In addition, liquid authority structures will have implications for the kinds of institutional mechanisms able to provide adequate public assurance to addressees that valued governance functions are being appropriately supported. Multiplicity and dynamism of governing authorities can restrict both their public visibility and their taken-for-granted social standing, thus intensifying the need for active processes of public assurance as a basis for establishing deference. Here too, legitimizing mechanisms will need to adapt to these distinctive challenges of liquidity, through incorporating strong instruments for mobilizing and engaging communities of addressees as a pre-requisite for effective assurance processes. This proposition also resonates with prior research demonstrating that experimentalist mechanisms may have certain advantages over alternative mechanisms in performing the assurance element of legitimization functions when the liquidity of any authority structure produces poorly-understood organizational processes, or capriciously changing audiences and decision makers (Fossum 2012, Deleon 1998, 551-552).

These theoretical propositions point to some ways in which the liquidity of authority may shape the functional capacities of different legitimization mechanisms within particular governance contexts, but it is important to emphasise that we are not claiming liquidity to be the only contextual factor that may influence these capacities. Others-such as societal complexity (Simon 2010,728) and fluidity of participation in governance processes (Stripple 2006, Zurn 2004, Mason 2008)—have been established elsewhere as variables with significance, in some cases, in shaping the functional capacities of particular legitimization mechanisms. Nonetheless, since authority plays a critical role in the functioning of most complex governance systems operating on transnational scales, the dynamics of the relationship between liquid authority and legitimizing mechanisms warrant more systematic investigation than they have thus far received in established literatures.

\section{Legitimizing liquid authority in transnational business regulation: a case study} With our theoretical account of political legitimacy now in hand, we turn next to our case study of legitimization challenges confronting authorities involved in transnational business regulation-specifically, the governance of company-community land conflicts in the palm oil sector. This case enables us to undertake detailed examination of a prominent field of transnational governance in which liquid forms of authority have been widely documented in relevant scholarly literature, and extensive political energy has been invested in exploring practical institutional mechanisms through which such authority might be legitimized. This analysis draws on research conducted during 2012 and 2013 in Indonesia, ${ }^{2}$ where transnational land disputes have posed a major governance challenge, and prompted extensive efforts to establish problem-solving transnational authorities.

\footnotetext{
${ }^{2}$ Analysis draws on 62 interviews and focus groups involving over 150 individuals, including staff of companies and NGOs working on land management issues in the palm oil sector, Indonesian government officials, staff and Board Members of the Roundtable on Sustainable Palm Oil and International Finance Corporation Compliance-Advisor Ombudsman, and members of communities affected by palm oil production.
} 
Liquid authority in the governance of company-community land conflicts

Conflicts between companies and communities concerning ownership or use rights of land have recently become increasingly prominent on transnational political agendas. Political concern has been driven in part by intensified competition for land available to local and foreign investors in sectors such as mining, agribusiness and forestry (Borras, McMichael, and Scoones 2010, Institute for Human Rights and Business 2009, Oxfam International 2011). Political awareness of such conflicts has been reinforced by the transnational character of land-intensive business activity, whereby many companies directly involved in land acquisition are internationally owned, internationally financed, or dependent on international markets for product sales.

In the Indonesian palm oil sector, land conflicts between palm oil companies and communities have usually resulted from disputes concerning land boundaries, the legality of land purchasing or licensing processes, or the terms on which land-sharing arrangements between plantation owners and smallholders are established. In some cases, police, military or private security officials have used violence against disputing parties to enforce contested allocations of land (Colchester 2011, Institute for Policy Analysis of Conflict 2014, McCarthy 2012).

Governance of such conflicts - that is, systematic efforts to manage and where possible resolve them-involves interaction among a number of authoritative actors at transnational, national and sub-national levels. Our central focus here is on the transnational actors asserting authority within these governance processes. The first of these is the World Bank Group's International Finance Corporation Compliance Advisor Ombudsman (IFC-CAO), which is an independent accountability and grievance handling body designed primarily to manage conflicts associated with business activity funded by the World Bank's private sector lending arms, the IFC and the Multilateral Investment Guarantee Agency (MIGA). As its name suggests, the CAO comprises three elements: a Compliance auditor, which assesses the IFC's adherence to its own social and environmental policies; an Advisory arm, which advises the World Bank Group on how IFC/MIGA's social and environmental performance can be improved; and an Ombudsman arm, which provides recourse for people affected by IFC or MIGA projects, and facilitates mediation between companies, communities and other affected parties. ${ }^{3}$

The Ombudsman arm of the CAO-the most directly involved in managing individual land disputes-does not adjudicate the merits of any individual complaint, nor impose solutions. Rather, it provides dispute resolution specialists, who work with disputing parties to "identify and implement their own solutions". ${ }^{4}$ In performing its mediation function, it requests parties to recognize its authority as an expert and independent mediator, and to respect the ground rules of mediation worked out on a case by case basis through the mediation process. The most direct addressees of such authority claims are companies financed through IFC loans, who are expected as a condition of their loans to comply with the IFC's Performance Standards, which lay out detailed social and environment expectations regarding business activity. Addressees also include other parties to land disputes, such as members of local communities, other companies within palm oil supply chains, and government agencies involved in managing land disputes at the local level.

\footnotetext{
${ }^{3} \mathrm{http}: / /$ www.cao-ombudsman.org/about/whoweare/index.html

${ }^{4}$ http://www.cao-ombudsman.org/howwework/ombudsman/
} 
The second significant transnational actor engaged in governing these companycommunity conflicts is the Roundtable on Sustainable Palm Oil (RSPO), which is a multistakeholder governance scheme that sets social and environmental standards for business activity in the palm oil sector. The RSPO has established a formal Complaints System that incorporates a Dispute Resolution Facility, designed to facilitate the mediation of individual conflicts, and a Complaints Panel, which is empowered to adjudicate disputes arising from complaints, and provide recommendations to the RSPO Board on appropriate remedies. ${ }^{5}$ Corporate members of the RSPO are central addressees of the RSPO's authority claims; authority claims of more limited kinds are also directed to external parties to specific disputes, such as landowners, workers or smallholders affected by the business activity of RSPO members. Member companies are expected to adhere to the RSPO's social and environmental standards, and to submit to its complaint handling procedures when disputes arise. Other parties are subject to RSPO authority in the form of expectations to follow RSPO procedures regarding submission and management of disputes. Both the CAO and RSPO also address authority claims to a range of state and non-state actors whose 'deferential conduct' they seek in the form of political support, as well as provision of resources to support their ongoing operation.

The authority exercised by these actors is liquid in many dimensions; we focus here on those features of liquidity with particular relevance for legitimization processes. Liquidity is reflected first in the multiplicity of the actors and institutions exercising authority within governance processes. Such multiplicity entails not only nonexclusivity, whereby a plurality of actors and institutions exercise authority over the management of land conflicts. Transnational authority is also interactive in the sense that individual authorities rely in part for their effectiveness on their capacity to enlist the resources of other actors to support their own goals. Efforts by transnational mediators to build collaborative relationships with government officials to support the effectiveness of their own negotiation, monitoring or implementation processes illustrate this clearly. In this sense the authority of one actor can only be understood "in interplay with others" (Krisch, this volume).

The interactive processes through which multiple authoritative actors establish and exercise authority are closely linked in turn to the dynamic liquid properties of transnational authority. Addressees of the CAO and RSPO's authority have significant freedom to exit voluntarily the market relationships in which the authority of these institutions is grounded. Companies can repay their IFC loans early as a means of concluding formal contractual obligations to adhere to the IFC's Performance Standards, as the company Wilmar did following a prolonged IFC-CAO mediation in the Indonesian Jambi province. Companies also have the option of selling subsidiaries that become embroiled in particularly difficult conflicts-a strategy also employed by Wilmar in this case. Wilmar sold the relevant subsidiary in April 2013 to a company that was not an RSPO member, leading to the loss of RSPO as well as IFC-CAO authority over the dispute (Rofiq and Hidayat 2013). Such examples highlight the contingency and transience of the authority wielded by transnational dispute resolution institutions over land conflicts of these kinds.

\footnotetext{
${ }^{5}$ http://www.rspo.org/en/system components and terms of reference
} 
The informal liquid properties of these authorities are a product of the non-legal character of their dispute managing institutions. Although accepting an IFC loan entails binding obligations for companies to comply with the IFC Performance Standards, participation in mediations under the CAO's Ombudsman arm is voluntary, and the conflicting parties need to appoint CAO mediators by mutual agreement. Companies are incentivized to engage with such mediation processes either to avoid consequences for their ongoing access to IFC finance, or to guard against broader adverse reputational effects. The RSPO likewise lacks the capacity to command obedience, relying instead on the mobilization of other incentives or pressures.

Public accountability and pragmatic experimentalism as mechanisms of political legitimization With the key features of liquid authority in the context of our case laid out, we can now assess the prospects for legitimizing this authority. Here we examine two specific institutional mechanisms which we introduced earlier in the paper, and which we claim are particularly important as potential instruments for legitimizing liquid forms of authority within the context of our case study of transnational business regulation: public accountability and pragmatic experimentalism.

Although legitimization strategies of the CAO and RSPO have not been based explicitly or systematically on these institutional categories, both the CAO and the RSPO have in practice incorporated elements of each kind of mechanism, often combined in complicated and sometimes ambiguous ways. Both the RSPO and the CAO dispute resolution processes make reference to codified social and environmental standards, though neither relies exclusively on pre-determined standards as a basis for deciding appropriate responses. The RSPO's dispute handling mechanism is on paper much more closely tied to standards than is the CAO's Ombudsman function, and the CAO's Ombudsman mechanism relies more explicitly on experimentalist mechanisms than does the RSPO-referring explicitly in its self-description to its reliance on a 'problemsolving' method. Nonetheless, both types of mechanism are used to some extent by both bodies.

Our exploratory empirical analysis of this case indicates that there are important differences between the capacities of each mechanism type to perform its legitimizing function in relation to liquid transnational authority. First, these mechanism types differ in their capacities to adapt to the conditions of uncertainty, disagreement and change associated with liquid authority. When authority is liquid, expectations regarding the appropriate purposes and roles of authorities will often be unclear, shifting and contested in significant ways. The lack of clarity and agreement regarding expectations is importantly linked to the multiplicity of authorities making claims for their rulings, directives or standards to be decisive or at least influential over the manner in which land disputes are resolved. The dynamic features of liquid authority can further intensify uncertainty. Such dynamism is itself often intensified by informal properties of the authority, because many sources of power and ideas underpinning such authority are themselves highly dynamic, as actors opt in and out of non-binding authoritative relationships, and as perceptions of impartiality or expertise shift. Such conditions can undermine the functioning of accountability mechanisms, which rely on a stable framework of agreed expectations against which public checks and assurance processes can occur. 
In contrast, pragmatic experimentalist mechanisms require agreement between parties only on more incremental and contextually specific terms, to inform agreed choices about immediate courses of collective action. Such agreements can continue to adapt to changing circumstances, as the preferences, motivations and external pressures facing each actor shift, and as the configuration of actors itself evolves. Moreover, progress does not require deeper agreement about underlying objectives or reasons. This can be useful in enabling the mechanisms to manage conflict effectively, by increasing the likelihood of securing agreement between parties under fragile bargaining conditions. The CAO Ombudsman has facilitated horizontal dialogue between parties as a core element of its interventions in individual disputes, while the RSPO has facilitated multistakeholder dialogue in relation to contested policy issues through its policy Working Groups.

Pragmatic experimentalist and public accountability mechanisms differ also in their capacities to function effectively in the presence of informal features of liquid authority. The informal character of transnational authority weakens the RSPO's ability to draw on accountability-based legitimization mechanisms. The RSPO's Complaints Panel is designed to assess the merits of complaints regarding violations of RSPO standards, and to stipulate appropriate remedies. Legitimization of this authority depends on the RSPO's capacity to perform these functions and provide assurance to addressees that they have been performed. This capacity is significantly constrained by the RSPO's inability to 'command obedience' with agreed standards, procedures and designated remedies. The RSPO's persistent inability to enforce compliance on a consistent basisand their corresponding reluctance to prescribe remedies that they are unable to enforce-has been widely criticized.

In contrast, there are high levels of functional compatibility between the informal authority on which the CAO Ombudsman largely relies, and the pragmatic experimentalist mechanisms through which it seeks legitimization for this authority. The CAO Ombudsman depends in important respects on ideational forms of informal authority, via recognition of the expertise and impartiality of its professional mediators. The legitimization of this authority then requires that such expertise and impartiality both supports, and is seen publicly to support, effective dispute handling. This in turn depends on the capacity of mediators to assist communication, trust, and constructive dialogue between disputing parties, and to demonstrate such capacities to relevant addressees. There are consequently high levels of compatibility between the ideational character of the authority being exercised, and the competencies required for its effective legitimization.

Despite the superior capacities of pragmatic experimentalist mechanisms to adapt to conditions of liquid authority in these dimensions, their potential is limited by an important functional weakness. Political support for pragmatic experimentalist mechanisms has been somewhat undermined in this case by their perceived tendency to enable or even encourage weaker actors to negotiate away formally recognized rights, within a political context where power relations are highly unequal. Both the CAO Ombudsman and the RSPO complaints system have been criticized by many NGOs and community organizations for facilitating negotiated agreements in which communities agree to give up land to which many consider them to have moral and in some cases also legal rights. In this sense, the fear is that such pragmatic compromises 
may not only fail to protect the rights of weaker parties, but also provide a basis for legitimizing inequalities or rights violations.

In theory, accountability mechanisms can help to remedy power imbalances, through emphasizing the protection of agreed categories of rights and harnessing public justification, oversight or redress as means of constraining unequal power relations. In practice, the capacity for these functions to be performed under conditions of liquid authority is often significantly constrained. Nonetheless, many NGOs and community organizations see value in continuing to assert accountability principles, even when they are unlikely to be enforceable. To some extent this reflects the potential symbolic value of public support for such principles. Persistent support for accountability mechanisms can also have significant material consequences. Demands for accountability on terms that cannot be enforced in a specific social context often reflect a deliberate strategy of delegitimization by NGOs and their community partners: 'These are the standards you ought to be held to', they assert, 'and if you are not able to live up to them, then we will not defer to your authority'. Under certain conditions, which are difficult to predict, these delegitimizing strategies can bring about substantive change to prevailing norms and power relations, in ways that result in strengthened accountability mechanisms. Indeed, the very existence of independent recourse mechanisms for International Financial Institutions such as the IFC-CAO can be largely attributed to persistent NGO strategies of these kinds (Park 2005, Clark, Fox, and Treakle 2003).

Such political dynamics help us understand why many addressees of transnational authorities continue to regard accountability mechanisms as central instruments of legitimization, despite their functional weaknesses under conditions of liquid authority. For example, the RSPO's efforts to defend the capacity of its Complaints System to assess compliance with codified standards reflect pressure to satisfy the expectations of NGO addressees regarding such accountability mechanisms. The IFC has likewise experienced persistent pressure from many categories of addressees to bolster its accountability mechanisms as an important foundation for securing its legitimacy (Bissell and Nanwani 2009).

Since public accountability and pragmatic experimentalist mechanisms have differing yet complementary functional capacities, there is significant practical appeal in developing legitimization strategies that draw on elements of both. A combined approach may enable transnational authorities to adapt their legitimization strategies according to both the varying character of liquid or solid authority in a given context, and the varying political expectations of addressees. The IFC-CAO, for example, has been explicit in its adoption of different mechanisms for distinct purposes. Public accountability mechanisms play a major role in attempting to legitimize the World Bank Group's own role in financing companies that are direct parties to land conflicts, through the Compliance arm of the CAO, which assesses compliance of the IFC's private sector lending activity with World Bank policy. The World Bank exercises relatively solid forms of authority over its own internal governance processes and lending decisions, meaning that the Compliance arm can adopt relatively strong accountability mechanisms, thereby satisfying NGOs and other external constituencies making demands for accountability. In relation to its intervention in external disputes concerning companies it has financed, in contrast, its authority is much more liquid. 
This is reflected in the pragmatic experimentalist legitimization mechanisms on which the CAO Ombudsman largely relies.

Nonetheless, more systematic efforts to combine public accountability and pragmatic experimentalist mechanisms would require careful attention to the clarity and transparency with which these different types of mechanism are distinguished. Because one important function of legitimization mechanisms is to provide public assurance that governance processes and outcomes meet the expectations of addressees, clarity of expectations is required-at least at some broad level-for legitimization to occur. For example, although the RSPO Complaints Panel is constituted through formalized standards and redress systems characteristic of public accountability, in practice disputes taken to the RSPO have often relied heavily on informal negotiations between member companies and NGOs. Even though such informal processes have sometimes contributed positively to facilitating the resolution of disputes, the operation of such negotiations outside mutually agreed institutional processes has undermined the complaint system's legitimacy. ${ }^{6}$ As a result, legitimizing liquid authority in this context requires not only combining differing types of mechanisms in functionally appropriate ways, ${ }^{7}$ but also clearly institutionalizing and publicly communicating the functional distinctions between them.

\section{Conclusions}

In this article we have explored how 'liquid' forms of authority in transnational governance can achieve normative political legitimacy. We have argued that because the capacities of legitimizing mechanisms operate differently under varying authority structures, the institutional mechanisms required to legitimize governance institutions also depend upon and vary with the empirical characteristics of their authority structures. This implies not only that institutional mechanisms should vary according to context, but also that there may often be advantages to the creative mixing and fusion of familiar institutional models in response to varying governance contexts. Our analysis offers conclusions first at a contextually- and institutionally-specific level in relation to our case; and second with regard to broader understanding of how institutional prescriptions vary with context-a point that has methodological as well as substantive implications for ongoing research on transnational authority and legitimacy.

First, we have elaborated our overarching findings with a considerable degree of institutional specificity as they apply to the design of legitimization mechanisms employed in the transnational governance of corporate-community land conflict. In this case, we analyzed the interaction between liquid authority and two specific types of legitimization mechanism that have played an important role in this context: public accountability and pragmatic experimentalism. Analysis revealed severable notable strengths and weaknesses of these two mechanism types under conditions of liquid authority. Pragmatic experimentalist mechanisms were generally better equipped than standard accountability mechanisms to adapt to uncertainty, conflict and change, and to

\footnotetext{
${ }^{6}$ For example, one critical NGO report characterised the RSPO Complaint System as suffering from "unpredictable procedures, arbitrary actions and unclear motives, leading to the perceived mistrust of the Complaints System by complainants and defendants ... and loss of credibility" (Grassroots 2013, 21).

${ }^{7}$ The broad notion of a 'hybrid' governance approach, combining experimentalist modalities with more traditional institutions for protecting rights, has been widely advanced (De Búrca 2010, Super 2008, Alexander 2009).
} 
function effectively under conditions of informal authority. However, experimentalist mechanisms suffered potential weaknesses as means of protecting the rights of weaker parties when power relations were highly unequal. Based on these observations, we suggested in the context of our case that there may be advantages of a hybrid institutional model to enable public accountability and pragmatic experimentalist mechanisms to be adapted and combined in appropriate ways to reflect their differing capacities.

Second, our analysis has supplied the basis for some broader reflections on the implications of contextually varying authority structures for the design of legitimization mechanisms across a wider variety of transnational governance contexts. Our casespecific findings may have some degree of direct transferability to contexts in which similar structures of liquid authority are present. For example, analogous patterns of liquid authority have been documented in other contexts of transnational economic and environmental governance (Overdevest and Zeitlin, 2014; Eberlein et.al., 2014). Nonetheless, although the liquidity of authority is likely to be a vitally important factor influencing the capacities of legitimizing mechanisms, other contextual factors will also play a role in shaping such capacities. The contextual analysis of legitimization mechanisms for transnational governance authority must be sensitive to such complexities.

Our finding that varying configurations of transnational authority have important implications for the selection and design of legitimization mechanisms suggests a need for future research on normative legitimacy in transnational governance to engage more extensively and systematically with empirical investigation of varying transnational authority structures. Normative analysis of the problem of legitimacy in transnational governance thus cannot be primarily philosophical. Development of a future research program in this field would benefit from closer dialogue between scholars engaged in philosophically oriented work on legitimacy and those undertaking empirically oriented work-enabling insights from each to be more systematically linked. Future research could examine potential applications of our argument to a range of transnational governance issue areas-embodying varying authority structures, and a broader variety of legitimization mechanisms. Critical evaluation of other candidate legitimization mechanisms and their operation in other governance contexts would require separate application of the analytic strategy demonstrated in this paper, through which our theoretical account of normative political legitimacy has been applied through contextualized analysis of the valuable functions of governing authority, systemic threats to the performance of such functions, and plausible institutional remedies to those threats within a particular governance context. As such, our analysis can be read as supplying methodological as well as substantive guidance for future work on the political legitimacy of liquid authority across a variety of transnational governance contexts.

While much research remains to be done, the analysis presented in this paper offers some preliminary grounds for optimism that political legitimacy remains an institutional virtue worth pursuing in the transnational arena, despite the challenges that liquid authority presents to prospective architects of transnational governance institutions. Devising and adapting appropriate hybrid strategies is nonetheless likely to remain significantly constrained by the very instability and change in social and institutional relations that underpins the constitution and exercise of liquid forms of 
transnational authority. These more deeply rooted tensions between the liquidity and legitimacy of transnational authority appear likely to persist.

\section{References}

Abbott, K. W. and Snidal, D. 2009. "Strengthening International Regulation through Transnational New Governance: Overcoming the Orchestration Deficit", Vanderbilt Journal of Transnational Law, 42: 501-538.

Alexander, Lisa T. 2009. "Stakeholder Participation in New Governance: Lessons from Chicago's Public Housing Reform Experiment." Geo. J. on Poverty L. \& Pol'y 16:117.

Archibugi, D. 2008. The Global Commonwealth of Citizens: Toward Cosmopolitan Democracy. Princeton: Princeton University Press.

Beetham, David. 1991. The legitimation of power. London: Macmillan.

Bernstein, Steven, and Benjamin Cashore. 2007. "Can non-state global governance be legitimate? An analytical framework." Regulation \& Governance 1(4): 347-371.

Bissell, Richard E., and Suresh Nanwani. 2009. "Multilateral development bank accountability mechanisms: developments and challenges." Manchester Journal of International Economic Law 6 (1):2-55.

Black, Julia. 2008. "Constructing and contesting legitimacy and accountability in polycentric regulatory regimes." Regulation \& Governance 2(2): 137-164.

Bohman, J. 2007. Democracy Across Borders. Cambridge, Mass.: MIT Press.

Borras, S M., Philip McMichael, and Ian Scoones. 2010. "The politics of biofuels, land and agrarian change: editors' introduction." The Journal of Peasant Studies 37 (4):575-592.

Bovens, Mark. 2007. "Analysing and Assessing Accountability: A Conceptual Framework." European Law Journal 13 (4):447-468.

Buchanan, Allen, and Robert 0. Keohane. 2006. "The legitimacy of global governance institutions." Ethics \& international affairs 20 (4):405-437.

Búrca, Gráinne De, Robert O. Keohane, and Charles Sabel. 2014. "Global Experimentalist Governance." British Journal of Political Science 44 (3): 477-486.

Búrca, Gráinne De. 2010. "New governance and experimentalism: An introduction." Wis. L. Rev: 227.

Cabrera, L. 2005. Political Theory of Global Justice: A Cosmopolitan Case for the World State. London: Routledge.

Cashore, Benjamin. 2002. "Legitimacy and the privatization of environmental governance: How non-state market-driven (NSMD) governance systems gain rule-making authority." Governance 15 (4):503-529.

Clapp, Jennifer. 2005. "Global Environmental Governance for Corporate Responsibility and Accountability." Global Environmental Politics 5 (3):23-34.

Clark, Dana, Jonathan A. Fox, and Kay Treakle, eds. 2003. Demanding Accountability: Civil Society Claims and the World Bank Inspection Panel. Washington, DC: Rowman \& Littlefield Publishers.

Colchester Marcus, Norman Jiwan, Andiko, Martua Sirait, Asep Yunan Firdaus, A. Surambo and Herbert Pane 2006. Promised Land Palm Oil and Land acquisition in Indonesia - implications for local communities and indigenous peoples. Forest 
Peoples Program, Perkumpulan Sawit Watch, HuMA and the Worls Agroforestry Center.

Colchester Marcus, Patrick Anderson, Asep Yunan Firdaus, Fatilda Hasibuan, Sophie Chao. 2011. Human rights abuses and land conflicts in the PT Asiatic Persada concession in Jambi: report of an independent investigation into land disputes and forced ev ictions in a palm oil estate. edited by Forest Peoples Program: Forest Peoples Program.

Cutler, A. Claire, Virginia Haufler, and Tony Porter. 1999. Private authority and international affairs, SUNY series in global politics. Albany: State University of New York Press.

De Búrca, Gráinne. 2010. "New governance and experimentalism: An introduction." Wis. L. Rev.:227.

Deleon, Linda. 1998. "Accountability in a 'reinvented'government." Public Administration 76 (3):539-558.

Dorf, Michael C., and Charles F. Sabel. 1998. "A constitution of democratic experimentalism." Columbia law review: 267-473.

Dorf, Michael C. 2003. "Legal Indeterminacy and Institutional Design." NYUL Rev. 78:875.

Dryzek, John. 2001. "Legitimacy and economy in deliberative democracy." Political Theory 29(5): 651-669.

Dryzek, John. 2006. Deliberative Global Politics: Discourse and Democracy in a Divided World. Cambridge: Polity.

Duit, A. and V. Galaz. 2008. "Governance and Complexity - Emerging Issues for Governance Theory." Governance: An International Journal of Policy, Administration, and Institutions 21(3): 311-335.

Eberlein, B., Abbott, K. W., Black, J., Meidinger, E., \& Wood, S. 2014. Transnational business governance interactions: Conceptualization and framework for analysis. Regulation \& Governance, 8(1): 1-21.

Erman, Eva. 2015. “Global political legitimacy beyond justice and democracy?" International Theory. DOI: 10.1017/S1752971915000196

Fossum, John Erik. 2012. "Reflections on experimentalist governance." Regulation \& Governance 6 (3):394-400.

Gehring, Thomas, and Sebastian Oberthür. 2009. "The causal mechanisms of interaction between international institutions." European Journal of International Relations 15(1): 125-156.

Geuss, Raymond. 2008. Philosophy and real politics. Princeton: Princeton University Press.

Goodhart, Michael. 2014 "Accountable International Relations." In Oxford Handbook of Public Accountability, edited by Mark Bovens, Robert E Goodin and Thomas Schillemans. Oxford: Oxford University Press.

Grant, Ruth, and Robert Keohane. 2005. "Accountability and Abuses of Power in World Politics." American Political Science Review 99 (1).

Grassroots. 2013. Beyond Certification: Reforming RSPO's Complaints System to meet stakeholder expectation. Kuala Lumpur: Grassroots.

Habermas, J. 2013. “A political constitution for the pluralist world society?", Journal of Chinese Philosophy 40(1): 226-238.

Hall, Rodney Bruce, and Thomas J. Biersteker. 2002. The emergence of private authority in global governance, Cambridge studies in international relations ; 85. Cambridge: Cambridge University Press. 
Held, D. 1995. Democracy and the Global Order: From the Modern State to Cosmopolitan Governance. Stanford: Stanford University Press.

Held, David, and Mathias Koenig-Archibugi, eds. 2005. Global governance and public accountability: Blackwell.

Institute for Human Rights and Business. 2009. Preventing Conflicts Over Land: Exploring the role of business and the value of human rights approaches. London: Institute for Human Rights and Business,.

Institute for Policy Analysis of Conflict. 2014. Indigenous Rights vs Agrarian Reform in Indonesia: A Case Study from Jambi. Jakarta: Institute for Policy Analysis of Conflict.

Kahler, Miles. 2009. Networked politics: agency, power, and governance. Ithica, NY: Cornell University Press.

Kjaer, Poul F. 2010. "The metamorphosis of the functional synthesis: a continental European perspective on governance, law, and the political in the transnational space." Wisconsin Law Review, 2: 489.

Koenig-Archibugi, Mathias. 2010. "Accountability in transnational relations: how distinctive is it?" West European Politics 33(5):1142-1164.

Kuyper, Jonathan W. 2014. "Global democratization and international regime complexity." European Journal of International Relations 20(3): 620-646.

Little, Adrian. 2015. "Performing the demos: towards a processive theory of global democracy." Critical Review of International Social and Political Philosophy 18(6): 620-641.

Macdonald, Kate and Macdonald, Terry. 2010. "Democracy in a Pluralist Global Order: Corporate Power and Stakeholder Representation:, Ethics \& International Affairs, 24(1): 19-43.

Macdonald, Terry. 2008. Global Stakeholder Democracy: Power and Representation Beyond Liberal States. New York: Oxford University Press.

Macdonald, Terry. 2011. "Citizens or Stakeholders? Problems of Exclusion and Inequality in Global Stakeholder Democracy". In Daniele Archibugi, Mathias Koenig-Archibugi \& Raffaele Marchetti, eds, Global Democracy: Normative and Empirical Perspectives. Cambridge: Cambridge University Press: 47-67.

Macdonald, Terry. 2015. "Political Legitimacy in International Border Governance Institutions", European Journal of Political Theory 14(4): 409-428.

Macdonald, Terry. 2016. "Institutional Facts and Principles of Global Political Legitimacy", Journal of International Political Theory 12(2): 134-151.

Mason, Michael. 2008. "The governance of transnational environmental harm: addressing new modes of accountability/responsibility." Global Environmental Politics 8 (3):8-24.

McCarthy, John F. 2012. "Certifying in Contested Spaces: private regulation in Indonesian forestry and palm oil." Third World Quarterly 33 (10):1871-1888.

Meidinger, E. 2008. "Competitive Supranational Regulation: How could it be democratic?" Chicago Journal of International Law, 8: 513-34.

Mitchell, Ronald B. 2006. "Problem structure, institutional design, and the relative effectiveness of international environmental agreements." Global Environmental Politics 6 (3):72-89.

Mulgan, Richard. 2000. "'Accountability': An Ever-Expanding Concept?" Public Administration 78 (3).

NeJaime, Douglas. 2009. "When new governance fails." Ohio St. LJ 70:323. 
Newell, Peter. 2008. "Civil society, corporate accountability and the politics of climate change." Global Environmental Politics 8 (3):122-153.

Overdevest, Christine, and Jonathan Zeitlin. 2014. "Assembling an experimentalist regime: Transnational governance interactions in the forest sector."Regulation \& governance 8(1): 22-48.

Oxfam International. 2011. Land and Power: The growing scandal surrounding the new wave of investment in land. London: Oxfam International.

Papadopoulos, Yannis. 2003. "Cooperative forms of governance: Problems of democratic accountability in complex environments." European Journal of Political Research 42(4): 473-501.

Park, Susan. 2005. "How transnational environmental advocacy networks socialize international financial institutions: A case study of the International Finance Corporation." Global Environmental Politics 5 (4):95-119.

Quack, Sigrid. 2010. "Law, expertise and legitimacy in transnational economic governance: an introduction." Socio-Economic Review 8: 3-16.

Pogge, Thomas. 1989. Realizing Rawls. Cornell University Press.

Pogge, Thomas. 1992. "Cosmopolitanism and sovereignty", Ethics 103(1): 48-75.

Rawls John. 1999. A Theory of Justice, rev. ed. Cambridge, MA: Belknap.

Rofiq, Rukaiyah, and Rian Hidayat. 2013. Mediation: a strategy or a final objective? Some notes based on the experience of mediating conflicts between PT Asiatic Persada and the Suku Anak Dalam (Batin Sembilan) in Jambi Province. Forest Peoples Programme.

Romzek, Barbara S, and Melvin J Dubnick. 1987. "Accountability in the public sector: Lessons from the Challenger tragedy." Public Administration Review:227-238.

Sabel, Charles F, and Jonathan Zeitlin. 2008. "Learning from difference: the new architecture of experimentalist governance in the EU." European Law Journal 14 (3):271-327.

Scholte, J A. 2004. "Civil Society and Democratically Accountable Global Governance." Government and Opposition 39:211-233.

Simon, William H. 2010. "New Governance Anxieties: A Deweyan Response." Wis. L. Rev.:727.

Skelcher, Chris. 2005. "Jurisdictional integrity, polycentrism, and the design of democratic governance." Governance 18(1): 89-110.

Steffek, Jens. 2003. "The legitimation of international governance: A discourse approach", European Journal of International Relations, 9(2): 249-275.

Stripple, Johannes. 2006. "Rules for the environment; reconsidering authority in global environmental governance." European Environment 16 (5):259-264.

Super, David A. 2008. "Laboratories of Destitution: Democratic Experimentalism and the Failure of Antipoverty Law." University of Pennsylvania Law Review:541-616.

Valentini, Laura. 2012. "Assessing the global order: justice, legitimacy, or political justice?." Critical Review of International Social and Political Philosophy 15(5): 593-612.

Vogel, David. 2010. "The Private Regulation of Global Corporate Conduct Achievements and Limitations." Business Society 49 (1):68-87.

Williams, Bernard. 2005. In the beginning was the deed: realism and moralism in political argument. Princeton: Princeton University Press.

Young, Katharine G., Sandra Liebenberg, and Karl Klare Social and Economic Rights in Theory and Practice: A Critical Assessment. Ed. Helena Alviar García, Lucy A. Williams. Abingdon, Oxon ; New York: Routledge, 2014. 2014. "Adjudicating 
Social and Economic Rights: Can Democratic Experimentalism Help?" " In Social and Economic Rights in Theory and Practice: A Critical Assessment, edited by Helena Alviar García, Karl Klare and Lucy A. Williams. Abingdon: Routledge. Zurn, Michael. 2004. "Global Governance and Legitimacy Problems." Government and Opposition 39 (2):260-287.

Zürn, Michael, and Benjamin Faude. 2013. "Commentary: On fragmentation, differentiation, and coordination." Global Environmental Politics 13(3):119-130. 